\title{
Demographic structure of a threatened palm (Euterpe edulis Mart.) in a fragmented landscape of Atlantic Forest in northeastern Brazil
}

\author{
Melina Oliveira Melito ${ }^{1,2,5}$, José Cláudio Faria ${ }^{3}$, André Márcio Amorim ${ }^{1,4}$ and Eliana Cazetta
}

Received: 23 March, 2013. Accepted: 7 November, 2013

\begin{abstract}
At the northern limits of the range of the palm species Euterpe edulis there is an endemic ecotype, known as the "Bahia" ecotype, which is distinguished by its reddish crownshaft and low seed production. Unfortunately, little is known about its demographic characteristics. Therefore, we contrasted the density of E. edulis populations in the Una region, in the southern part of the Bahia state, Brazil, with that of other populations of the species in southern and southeastern Brazil. In addition, within the Una region, we compared a long-protected forest fragment (F1) with three recently protected fragments (F2, F3, and F4), in terms of demographic parameters and plant size, in order to determine what influence, if any, time since protection has on E. edulis populations. Population densities within the Una region were higher than in regions where E. edulis populations are stressed by harvesting or intense seed predation but much lower than in regions with well protected populations. Among the Una fragments, density was highest in F1 and lowest in F2. The proportion of individuals at the various developmental stages differed among the fragments $\left(\chi^{2}=25.219\right.$, $\mathrm{df}=12, p=0.014)$. Diameter at ground level, height, and number of leaves correlated positively among themselves and negatively with population density. For all developmental stages, F1 surpassed the other fragments in terms of densities and plant sizes. It is likely that the newly protected populations suffer the lingering effects of previous harvesting, which are reflected in their demography and in the size of their individual members. The viability of this low-density endemic ecotype must be established in order to assess the conservation status of the species on a regional scale.
\end{abstract}

Key words: Juçara palm heart, forest fragment, life stages, recruitment, population structure

\section{Introduction}

Palms (Arecaceae) are important components of tropical and subtropical ecosystems (Uhl \& Dransfield 1987; Scariot 1999) and have key ecological functions in providing resources for vertebrate frugivores (Galetti \& Aleixo 1998; Galetti et al. 2006; Andreazzi et al. 2009). Because they are easily recognizable and of significant ecological importance, palms are highly appropriate subjects for demographic studies (Uhl \& Dransfield 1987).

The palm Euterpe edulis Mart. is considered a key species in fragmented forests and habitats with restricted resource offerings (Fadini et al. 2009) because it provides food resources for a variety of frugivorous vertebrates, including birds (Galetti \& Aleixo 1998; Matos \& Watkinson 1998), large mammals (Keuroghlian \& Eaton 2008), and rodents (Vieira et al. 2003). By attracting seed dispersers that can transport seeds from neighboring forest fragments,
E. edulis facilitates the recovery of degraded forest patches (Reis et al. 2000).

Commercial harvesting of Euterpe edulis palm trees may have serious effects on their population structure, especially in the context of fragmented landscapes (Portela et al. 2010a). Palm heart harvesting has resulted in declining natural populations of E. edulis (Galetti \& Fernandez 1998), and has negative effects on natural regeneration and the maintenance of their demographic structure (Reis et al. 2000). Euterpe edulis populations are believed to be decreasing even in protected forest fragments (Portela et al. 2010b). Palm heart harvesting has a negative impact on biodiversity, not only through the direct effects that palm heart gatherers have on the forest by hunting (Matos \& Bovi 2002) but also through the indirect effect of a loss of resource availability for local animals (Galetti \& Aleixo 1998; Matos \& Bovi 2002).

Euterpe edulis occurs in the Atlantic Forest, which extends along the coast of Brazil, from the state of Rio Grande do

\footnotetext{
${ }^{1}$ Universidade Estadual de Santa Cruz, Departamento de Ciências Biológicas, Programa de Pós-Graduação em Ecologia e Conservação da Biodiversidade, Ilhéus, BA, Brazil

${ }^{2}$ Universidade de São Paulo, Instituto de Biociências, Programa de Pós-graduação em Ecologia, São Paulo, SP, Brazil

${ }^{3}$ Universidade Estadual de Santa Cruz, Departamento de Ciências Exatas e Tecnológicas, Ilhéus, BA, Brazil

${ }^{4}$ Herbário Centro Pesquisas do Cacau, Ilhéus, BA, Brazil

${ }^{5}$ Author for Correspondence: melinamelito@gmail.com
} 
Norte to the state of Rio Grande do Sul, as well as stretching into inland areas of central Brazil and into the Misiones region of Paraguay and Argentina (Henderson et al. 1995). Although E. edulis is widely distributed, studies focusing on its demographic structure have largely been concentrated on southern and southeastern Brazil (Reis et al. 1996, Silva Matos et al. 1999, Portela 2008). In northeastern Brazil, the population structures of E. edulis have been analyzed only in the Una region (Silva et al. 2009), which is in the southern portion of the state of Bahia.

Southern Bahia contains some of the last remaining forest fragments of the northeastern Atlantic Forest (Faria et al. 2009), a region considered to be of great biological importance because of its high levels of species richness and plant endemism (Thomas et al. 1998; Martini et al. 2007; Thomas et al. 2008). The tropical lowland rain forest in the Una region shows very high plant diversity and endemism, with distinct canopy, understory, and emergent layer structures, together with a rich epiphytic flora of bromeliads, orchids, ferns, and lianas (Thomas et al. 1998; Amorim et al. 2008). However, the forests of the Una region have suffered from massive deforestation and intense logging activities since the 1970s (Alger \& Caldas 1994), and the remaining forest fragments are estimated to represent only $9.4 \%$ of the original cover (excluding open water, according to Saatchi et al. 2001).

The best approach to determining population viability is the estimation of demographic rates by studies of population dynamics (Virillo et al. 2011). Analyses of population dynamics generally require long-term studies and there are always difficulties in implementing, managing, and financially supporting this type of research, as was pointed out by Bruna \& Kress (2002) and Bruna et al. (2009). Although the current demographic structure of a population allows only limited insights (Virillo et al. 2011), it may be a useful measure for the immediate evaluation of conservation status (Bruna \& Kress 2002). When evaluating multiple populations of a single species, deviations in certain demographic attributes can be observed (Bruna \& Kress 2002). Therefore, the current structure of a population can provide information for making recommendations regarding the sustainable management of tropical forest products.

Previous studies have indicated that the populations of Euterpe edulis found in the state of Bahia constitute an endemic ecotype, with a phenotype (Bovi et al. 1987) and genotypes (Coelho 2010) that are distinct from those of the E. edulis populations in Atlantic Forest fragments in southeastern and southern Brazil. This "Bahia" ecotype (Bovi et al. 1987 ) is principally characterized by its reddish crownshaft and the reduced numbers of rachillae-which implies lower seed production (Silva et al. 2009). Low seed production can lead to reduced recruitment of seedlings into the population, ultimately resulting in a population with fewer individuals. Plant demography is also negatively affected by time since the onset of protection of the population, which reflects in the vulnerability of a forest to selective logging, game hunting, and palm heart extraction. Forests from Una region has a historical of selective logging (Mesquita 1996) which could lead to disturbed areas by removal of big trees and soil disturbances reflecting, ultimately, in seed limitation process (Clark et al. 2007). Illegal game hunting species is also an activity practiced by nearly $40 \%$ of the families in the surroundings of the protected areas under study, being one of the major threats to the fauna of the region (Pardini 2001). Depletion of game species can promote compensatory increases in the guild of granivorous, which can increase seed predation rates (Donoso et al. 2003). Seed predation is a process that directly affects plant demography (Hulme 1998) by limiting the recruitment of new individuals into the plant population. Palm exploitation also affects plant demography by increasing the mortality of reproductive individuals. In addition, palm exploitation affects the tree size average because it is focused on the tallest individuals (Matos \& Bovi 2002) and could result, in the long term, in populations composed of shorter individuals.

Within this context, we compared the density of E. edulis in this distinct edaphic-climatic Una landscape with that reported for E. edulis populations in southern and southeastern Brazil. We hypothesized that the "Bahia" ecotype characteristic of the Una region would show a low number of individuals in comparison with the other populations. Furthermore, we analyzed the demographic structure of $E$. edulis to compare a long-protected forest fragment in the Una region with three other fragments that had only recently been granted protected status, in terms of demographic parameters and plant sizes. We assumed that the long-protected forest fragment would provide the best conditions for the growth and development of E. edulis. Therefore, we expected the values for the demographic parameters-density, reproductive output, and population structure-as well as for the plant size parameters-height, diameter at ground level (DGL), and number of leaves-to be higher in the long-protected forest fragment than in the newly protected forest fragments. Consequently, the objectives of the present study were to compare E. edulis populations in the Una region with those in southern and southeastern Brazil, in terms of density; to determine whether the population structure in the longprotected forest fragment in the Una region is similar to that of the more recently protected forest fragments in the same region; to compare the reproductive outputs of the seedling and sapling banks in the forest fragments in the Una region; and to compare the long-protected and newly protected forest fragments in the Una region, in terms of plant size patterns.

\section{Materials and methods}

\section{Study site}

The present study was conducted in two contiguous federally protected areas: the Una Reserva Biológica (RE$\mathrm{BIO}$, Biological Reserve); and the surrounding Una Refúgio 
de Vida Silvestre (RVS, Wildlife Refuge). The Una REBIO is a highly protected area established in 1980, designated for scientific research and biodiversity protection. This protected area incorporated additional forest fragments in 2007 and now covers a total of 18,900 ha. The Una RVS was established in 2007 with less rigorous protection that allows private ownership in an integrated system of land use, which promotes the recuperation of disturbed areas to reconnect and protect forest fragments.

Employing land use and land cover estimates obtained from radar imagery (of an area roughly $100 \mathrm{~km} \times 50 \mathrm{~km}$ ), Saatchi et al. (2001) showed that the landscape of the Una region (excluding open water) comprises old-growth forest $(9.4 \%)$, surrounded by a matrix composed principally of flooded vegetation (15.4\%), shade cacao plantations (15.0\%), rubber plantations (10.9\%) and pasture (4.3\%). Forest fragments in the Una region show an irregular shape increasing the contact with the non-forested matrix (Pardini 2001).

Within the two protected areas, there is a mosaic of forest fragments. We sampled four fragments that showed no visible signs of palm heart harvesting, designated $\mathrm{F} 1$, F2, F3, and F4 (Fig. 1), with total areas of 12,334 ha, 2,655 ha, 946 ha, and 210 ha, respectively. The largest fragment (F1) has been a protected area since 1980, whereas the other fragments were not granted protected status until 2007. Areas F1 and F3 now belong to the Una REBIO and $\mathrm{F} 2$ and F4 are within the legally protected domain of the Una RVS. Based on the radar imagery of the region (Saatchi et al. 2001), all of the fragments sampled are categorized as old-growth forest.
The study area is characterized by two principal soil types: spodosols (variety Cururupe [Tropodult]) in the east; and oxisols (laterites, variety Tabuleiro [Haplorthox]) in the west (Carvalho Filho et al. 1987). The average annual temperature in the region is $24^{\circ} \mathrm{C}$, and the mean annual rainfall is ca. $2000 \mathrm{~mm}$, without any distinct seasonality, although there is often less precipitation from December to March (Mori et al. 1983).

\section{Demographic census samples}

At each sampling site, we established three $25 \mathrm{~m} \times 25 \mathrm{~m}$ plots ( 0.19 ha each), spaced at least $50 \mathrm{~m}$ apart. The plots were distributed along pre-existing trails but always more than $50 \mathrm{~m}$ from any fragment edge. The F1 sampling site was accessible by a trail through the interior of a forest fragment near a river. We assumed that the density of Euterpe edulis was unrelated to its proximity to the river, because, in a previous study conducted at Una (A. M. Z. Martini, unpublished data), no such correlation was found, probably because of the already high levels of humidity in the region.

The sampling plots were subdivided into $5-\mathrm{m}$ grids in which all individuals of Euterpe edulis were counted and measured. We evaluated the following morphometric characteristics: number of leaves; type of leaves (palmate or pinnate); height at leaf insertion; and DGL above the root cone, a measurement shared by all individuals (Silva Matos et al. 1999). The individuals were then classified into development stages that were based on biological criteriasigns of reproduction and plant size (adapted from Silva et al. 2009): seedling-one palmate leave and an endosperm
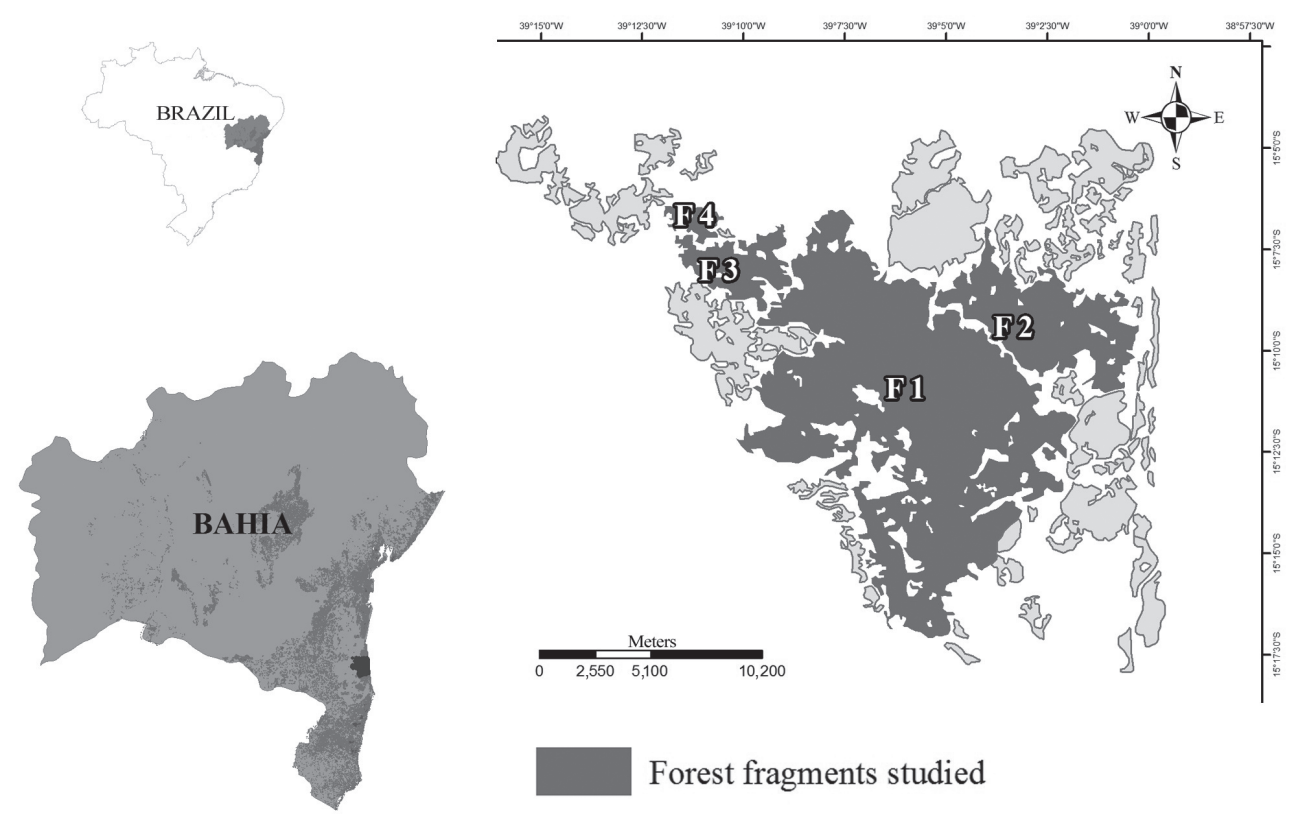

Figure 1. Locations of the fragments of Atlantic Forest studied (F1, F2, F3, and F4) in the Una region, located in the state of Bahia, Brazil. On the left, the Una region is highlighted, and the right panel shows the forest fragments that compose the two contiguous protected areas (the Una Biological Reserve and the Una Wildlife Refuge). 
reserve; sapling_-pinnate leaves, although palmate leaves might still be present, height $\leq 0.15 \mathrm{~m}$; juvenile-pinnate leaves only, height $\leq 1 \mathrm{~m}$; immature-stem $>1 \mathrm{~m}$ with no sign of reproductive events; and adult - stems with signs of reproductive events. The survey was undertaken near the end of the fruiting season, from August to October 2010.

\section{Data analyses}

We compared the density of Euterpe edulis populations in the Una region with that of those in the southern and southeastern regions of the Atlantic Forest biome by calculating the numbers of plants per hectare, on the basis of data presented in previously published studies. A list of the studies analyzed is shown in Tab. 1.

The data were analyzed using traditional parameters of descriptive statistics, including means, standard deviations, and confidence intervals (Zar 2009). We used the confidence intervals around the mean to compare plant densities within the different forest fragments. Means and confidence intervals were calculated considering the numbers of individuals per subplot (0.0025 ha).
Reproductive output was quantified by calculating the seedling/adult and sapling/adult ratios. The population structures of the fragments were analyzed considering the proportions of individuals in each developmental stage, using Pearson's chi-square test $\left(\chi^{2}\right)$. In addition, we used cluster analysis to group the fragments on the basis of similarities in the proportions of plants at each development stage.

To summarize the variances and covariances of plant size parameters and densities among the developmental stages and fragments, we used ordination techniques, constructing a biplot obtained from principal component analyses that represented simultaneously the sample units and variables of an $n \times p$ correlation matrix (Gabriel 1971). In the analyses, points lying close together indicated similarities among objects (sample units) related to the scores of the principal component axes. The response variables were the vectors, and the angulations formed between them indicated the degrees of correlation among the variables (Gabriel 1971). We considered the density of Euterpe edulis and plant size parameters (DGL, height, and number of leaves) as the multivariate variables (vectors). For each fragment, the development stages were considered sampling units; we

Table 1. Locations, forest fragment sizes, areas sampled in each fragment, and densities of natural populations of Euterpe edulis studied within the Atlantic Forest Biome of Brazil.

\begin{tabular}{|c|c|c|c|c|}
\hline Municipality (state) & Forest area (ha) & Area(s) sampled (ha) & Density (ind./ha) & Reference \\
\hline Una (BA), Fragment 1 & 12,334 & 0.19 & 4,677 & \multirow{4}{*}{ Present study } \\
\hline Una (BA), Fragment 2 & 2,655 & 0.19 & 1,104 & \\
\hline Una (BA), Fragment 3 & 946 & 0.19 & 2,981 & \\
\hline Una (BA), Fragment 4 & 210 & 0.19 & 2,661 & \\
\hline Una (BA) & 383 & 0.61 & 4,232 & Silva et al. (2009) \\
\hline Una (BA) & 12,334 & 0.12 and $0.004^{\star}$ & 4,559 & Martini** $^{* *}$ \\
\hline Casimiro de Abreu (RJ) & 19 & 0.81 & $112^{* * *}$ & \multirow{5}{*}{ Portela (2008) } \\
\hline Casimiro de Abreu (RJ) & 21 & 0.81 & $162^{* * *}$ & \\
\hline Casimiro de Abreu (RJ) & 57 & 0.81 & $176^{* * *}$ & \\
\hline Casimiro de Abreu (RJ) & 3,500 & 0.81 & $974^{* * *}$ & \\
\hline Silva Jardim (RJ) & 2,400 & 0.81 & $22^{* * *}$ & \\
\hline Sete Barras (SP) & 164 & ND & $17,914^{* * * *}$ & Reis et al. (2000) \\
\hline Campinas (SP) & 252 & 0.25 & 3,780 & Silva-Matos (2000) \\
\hline Anchieta (SP) & 806 & 0.8 & 154 & \multirow{2}{*}{ Fadini et al. (2009) } \\
\hline Caraguá (SP) & 39,800 & 0.8 & 1,860 & \\
\hline São Francisco do Sul (SC) & 9 & 1.0 and $0.04^{*}$ & 2,350 & Meyers \& Dornelles (2003) \\
\hline Blumenau (SC) & ND & 5.44 & 17,200 & Reis et al. (1996) \\
\hline Blumenau (SC) & 2,200 & ND & 8,450 & \multirow{2}{*}{ Reis et al. (2000) } \\
\hline São Pedro de Alcântara (SC) & 35 & ND & $17,966^{* * * *}$ & \\
\hline Maquiné (RS) & ND & 0.26 & 5,343 & Raupp et al. (2009) \\
\hline
\end{tabular}

ind. - individuals; BA - Bahia; RJ - Rio de Janeiro; SP - São Paulo; SC - Santa Catarina; RS - Rio Grande do Sul; ND - no data.

* The first value is the area for individuals with exposed stem $>100 \mathrm{~cm}$ in height; the second value is the area for individuals $<100 \mathrm{~cm}$ in height.

** Unpublished data collected in 2000.

$* * *$ Values represent the means of three years.

$* * * *$ Values represent the means of two years. 
excluded the seedling class from analyses because there were no plant size measurements for that class. For biplot construction, the mean values were centered and standardized because of the different measurement scales used. All statistical analyses were performed using $\mathrm{R}$ environment software, version 2.13.1 (R Development Core Team 2009).

\section{Results}

The study sites and populations compared are detailed in Tab. 1. Density (individuals per hectare) was highest in F1 $(\mathrm{n}=4,677 / \mathrm{ha})$, followed by F3 $(\mathrm{n}=2,981 / \mathrm{ha}), \mathrm{F} 4(\mathrm{n}=$ $2,661 / \mathrm{ha})$, and F2 ( $\mathrm{n}=1,104 / \mathrm{ha})$. All Euterpe edulis populations in the Una region showed densities that were lower than those reported for E. edulis populations in other states: by Reis et al. (2000) for São Paulo $(\mathrm{n}=17,914 / \mathrm{ha})$; by Reis et al. $(1996 ; 2000)$ for Santa Catarina $(\mathrm{n}=17,200 / \mathrm{ha}$ and 17,966/ha, respectively); and by Raupp et al. (2009) for Rio Grande do Sul ( $\mathrm{n}=5,343 / \mathrm{ha}$ ). Densities for F2, F3, and F4 were also lower than the 3,780 individuals/ha reported for the state of São Paulo by Silva-Matos (2000), as well as being lower than the 4,232 individuals/ha and 4,559 individuals/ ha previously reported for other areas sampled in the Una region by Silva et al. (2009) and A. M .Z. Martini (unpublished data), respectively. Although density was lower in F2 than in the other Una region fragments, it was higher than a number of areas studied in the state of Rio de Janeiro (Portela 2008) and on an island in the state of São Paulo (Fadini et al. 2009).

Overall, the mean density of Euterpe edulis was greater in F1 (292 \pm 62 plants/ha) than in the other Una fragments: F2 (69 \pm 27 plants/ha); F3 (186 \pm 123 plants/ha); and F4 (166 \pm 42 plants/ha). Plant density per plot was highest in $\mathrm{F} 1$ and lowest in F2 (Fig. 2). The reproductive output of seedlings was at least four times greater in $\mathrm{F} 4$ than in the other Una fragments (Fig. 3a). The sapling/adult ratio varied relatively little among the fragments but was nearly two times higher in F3 (Fig. 3b).

The population structures varied significantly among the Una fragments $\left(\chi^{2}=25,219, \mathrm{df}=12, p=0.014\right)$. In general, at least half of all individuals were concentrated in the sapling stage (Fig. 4). The lowest proportions of plants were observed at the seedling and adult stages (Fig. 4). On the basis of the proportions of individuals (Fig. 4 and 5), F1 and F2 showed similar structures; F4 formed an intermediate group, largely due to the higher proportion of seedlings (11.8\%); and F3 showed the greatest dissimilarity in relation to the other fragments, with the highest proportion of saplings (65.8\%), resulting in the lowest proportions of juvenile plants (26.5\%), immature plants (3.8\%), and adults (1.8\%).

The biplot showed a weak association between density and plant size in Euterpe edulis (Fig. 6). The morphometric variables showed strong positive correlations with each other and negative correlations with plant density (Fig. 6, Tab. 2). The first principal component (PC1) explained

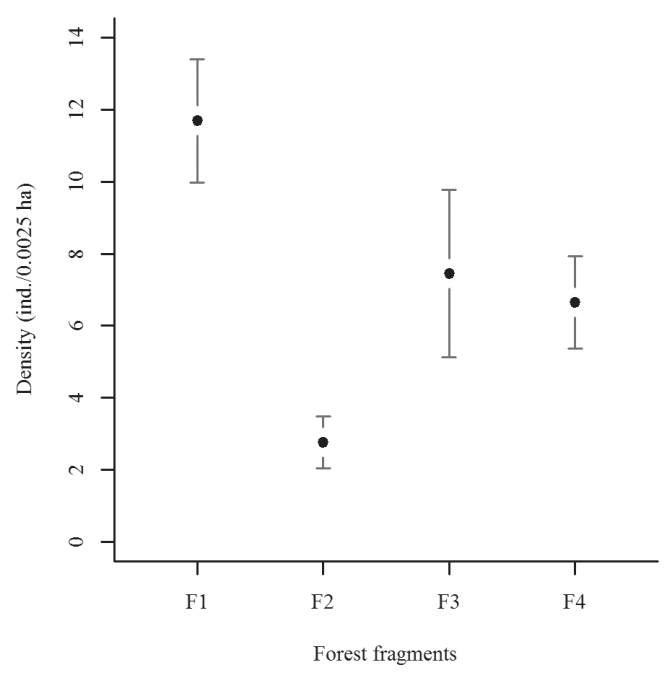

Figure 2. Mean density (individuals per 0.0025 ha) of Euterpe edulis in forest fragments in the Una region, located in the state of Bahia, Brazil.* ind. - individuals.

*The bars indicate the confidence intervals around the means.
A

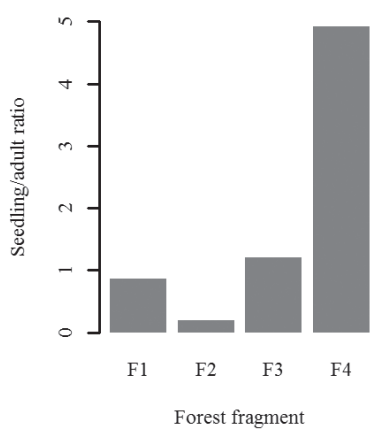

B

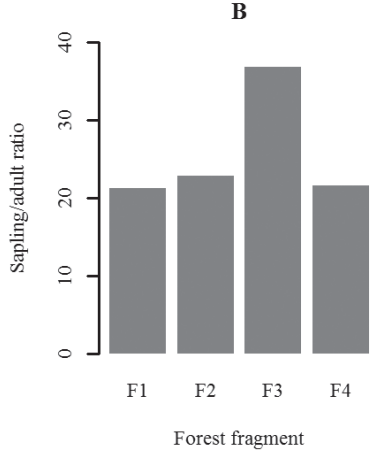

Figure 3. Seedling/adult ratio (A) and sapling/adult ratio (B) of Euterpe edulis in four forest fragments in the Una region, located in the state of Bahia, Brazil.

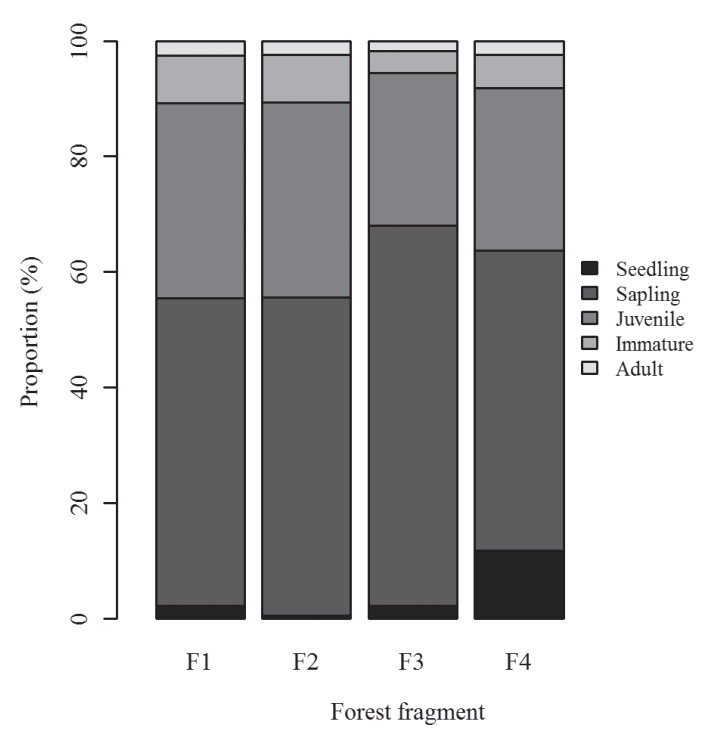

Figure 4. Population structure of Euterpe edulis based on the proportions of plants at five developmental stages in forest fragments in the Una region, located in the state of Bahia, Brazil. 


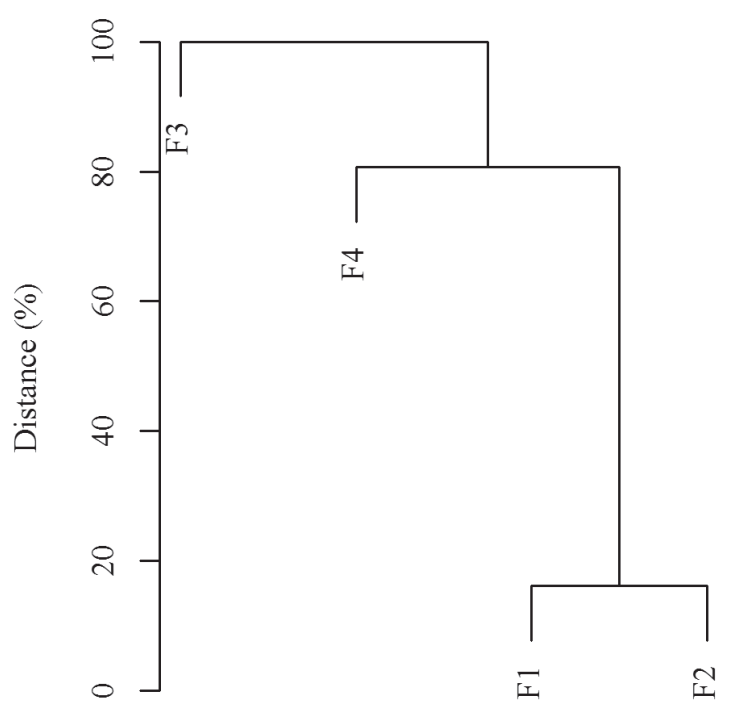

Figure 5. Cluster analysis, illustrating the similarities among Euterpe edulis populations, based on the proportions of individuals at the five developmental stages monitored in forest fragments in the Una region, located in the state of Bahia, Brazil.

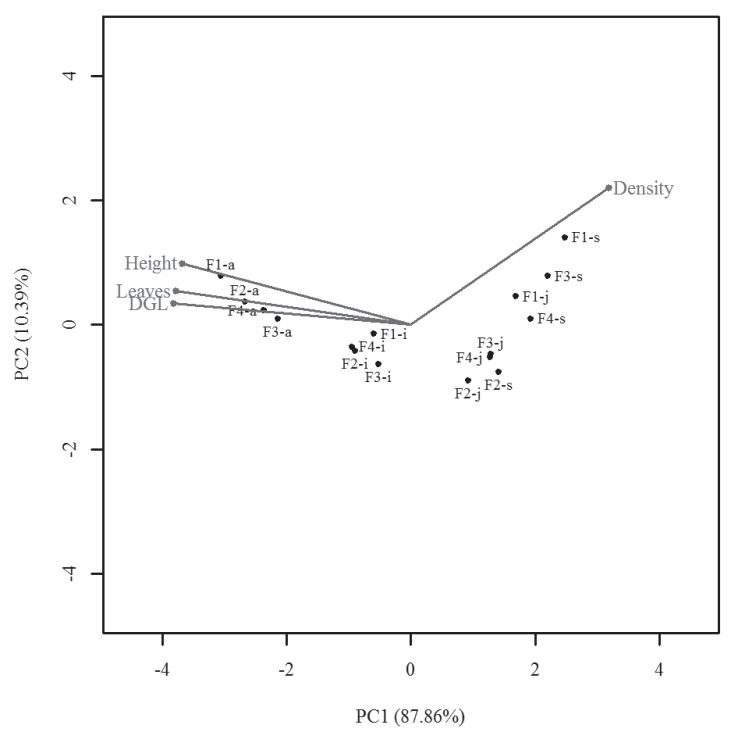

Figure 6. Biplot based on principal component analyses of the relationships that density has with the variables (vectors) of plant size (diameter at ground level, leaf number, and height) at the various developmental stages in Euterpe edulis populations in four forest fragments (F1, F2, F3 and F4) in the Una region, located in the state of Bahia, Brazil.

PC - principal component; DGL - diameter at ground level; Leaves - number of leaves; Density - number of individuals per ha; $s$ - sapling stage; $j$ - juvenile stage; $\mathrm{i}$ - immature stage; a - adult stage.

$87.9 \%$ of the variation, discriminating the sample units on the right side of the first axis with greater values of plant density, contrasting with greater plant sizes (DGL, height, and number of leaves) on the left side (Fig. 6). In PC1, we observed a consistent pattern of the number of individuals decreasing in parallel with increases in plant size (Fig. 6). The sapling stage had the greatest number of individuals, followed by the juvenile stage, and there were overlaps in
Table 2. Correlation matrix of plant size parameters and densities of Euterpe edulis populations in four forest fragments in the Una region, located in the state of Bahia, Brazil.

\begin{tabular}{lccc}
\hline \multirow{2}{*}{ Parameter } & \multicolumn{3}{c}{ Parameter } \\
\cline { 2 - 4 } & Density & DGL & Height \\
\hline Density & - & & \\
DGL & -0.76 & - & \\
Height & -0.64 & 0.95 & - \\
Leaves & -0.72 & 0.98 & 0.94 \\
\hline
\end{tabular}

DGL - diameter at ground level; Height - plant height; Leaves - number of leaves.

the densities of these stages between the different fragments (Fig. 6, Tab. 3). In F1 and F2, the density of juvenile plants was similar to that of saplings (Fig. 6, Tab. 3). Adults showed larger plant sizes but lower densities, the density of adults being highest in F1 (Fig. 6, Tab. 3). The second principal component (PC2) explained $10.4 \%$ of the remaining variation, discriminating the stages and fragments by plant density and height (Fig. 6, Tab. 3). The PC2 scores for all of the development stages were highest for F1, indicating that the plants there had higher densities and were taller (Fig. 6, Tab. 3). The lowest PC2 scores were for the seedling and juvenile stages in F2, as well as for the immature and adult stages in F3 (Fig. 6, Tab. 3).

\section{Discussion}

The densities of Euterpe edulis were higher in the Una forest fragments than in heavily impacted forest remnants (Portela 2008) and protected forest fragments in the state of Rio de Janeiro (Portela et al. 2010b), as well as in a forest patch where there was extensive seed predation by agoutis (Fadini et al. 2009). However, the densities of the Una populations of $E$. edulis were considerably lower than the 17,000 individuals/ha and 18,000 individuals/ha reported for E. edulis populations in fragments of Atlantic Forest in southern and southeastern Brazil, respectively (Reis et al. 1996; 2000). This corroborates our hypothesis that the phenotypically and genetically differentiated populations of E. edulis in the Una region-constituting the "Bahia" ecotype (Coelho 2010)-have lower densities than do other populations of the species in Brazil, except for the heavily impacted populations.

Although the plant density observed in F1 in the present study was the highest in the Una region, it was significantly lower than that of the high-density areas in the states of São Paulo and Santa Catarina (Reis et al. 1996, 2000). However, F1 had a higher density than did a swampland population in the state of São Paulo, where the species was considered abundant (Silva-Matos 2000). These patterns corroborate our assumption that the F1 fragment has the E. edulis population in a better conservation status in Una region. 
Table 3. Density of plants, plant sizes, and eigenvalues of the first and second principal components for the four development stages of Euterpe edulis in forest fragments in the Una region, located in the state of Bahia, Brazil.

\begin{tabular}{|c|c|c|c|c|c|c|c|}
\hline \multirow{3}{*}{ Stage } & \multirow{3}{*}{ Fragment } & \multirow{3}{*}{$\begin{array}{c}\text { Density } \\
\text { (ind./ha) }\end{array}$} & \multicolumn{3}{|c|}{ Plant size } & \multicolumn{2}{|c|}{ Eigenvalues } \\
\hline & & & DGL $(\mathrm{cm})$ & Height $(\mathrm{cm})$ & $\mathrm{N}^{\circ}$ of leaves & \multirow{2}{*}{ PC1 } & \multirow{2}{*}{ PC2 } \\
\hline & & & Mean \pm SD & Mean \pm SD & Mean \pm SD & & \\
\hline \multirow{4}{*}{ Sapling } & $\mathrm{F} 1$ & 2490 & $0.74 \pm 0.31$ & $8.34 \pm 3.68$ & $2.81 \pm 1.01$ & 24.80 & 14.03 \\
\hline & F2 & 608 & $0.80 \pm 0.32$ & $8.29 \pm 3.23$ & $2.64 \pm 0.86$ & 14.14 & -0.76 \\
\hline & F3 & 1962 & $0.80 \pm 0.33$ & $8.14 \pm 3.17$ & $2.51 \pm 0.81$ & 22.06 & 0.78 \\
\hline & $\mathrm{F} 4$ & 1381 & $0.66 \pm 0.33$ & $8.11 \pm 3.28$ & $2.32 \pm 0.72$ & 19.24 & 0.10 \\
\hline \multirow{4}{*}{ Juvenile } & $\mathrm{F} 1$ & 1578 & $2.50 \pm 1.50$ & $34.52 \pm 19.53$ & $3.28 \pm 1.09$ & 16.85 & 0.46 \\
\hline & F2 & 373 & $2.74 \pm 1.35$ & $32.28 \pm 16.56$ & $3.41 \pm 0.79$ & 0.93 & -0.90 \\
\hline & F3 & 789 & $2.47 \pm 1.32$ & $28.47 \pm 15.07$ & $2.96 \pm 0.86$ & 12.93 & -0.47 \\
\hline & $\mathrm{F} 4$ & 746 & $2.48 \pm 1.22$ & $33.48 \pm 15.70$ & $2.90 \pm 0.85$ & 12.72 & -0.52 \\
\hline \multirow{4}{*}{ Immature } & $\mathrm{F} 1$ & 389 & $9.42 \pm 2.97$ & $437.11 \pm 281.16$ & $6.30 \pm 2.40$ & -0.60 & -0.15 \\
\hline & $\mathrm{F} 2$ & 90 & $9.19 \pm 3.50$ & $410.92 \pm 224.29$ & $7.29 \pm 2.52$ & -0.90 & -0.42 \\
\hline & F3 & 112 & $8.74 \pm 3.31$ & $275.10 \pm 133.37$ & $5.71 \pm 1.71$ & -0.52 & -0.63 \\
\hline & $\mathrm{F} 4$ & 154 & $10.08 \pm 3.23$ & $396.43 \pm 199.09$ & $6.76 \pm 1.86$ & -0.94 & -0.35 \\
\hline \multirow{4}{*}{ Adult } & $\mathrm{F} 1$ & 117 & $14.66 \pm 2.62$ & $1291.67 \pm 323.63$ & $10.27 \pm 2.75$ & -30.58 & 0.78 \\
\hline & $\mathrm{F} 2$ & 26 & $17.10 \pm 3.01$ & $948.56 \pm 161.90$ & $9.00 \pm 3.54$ & -26.65 & 0.37 \\
\hline & F3 & 53 & $13.74 \pm 2.94$ & $696.81 \pm 154.61$ & $10.10 \pm 1.29$ & -21.40 & 0.09 \\
\hline & $\mathrm{F} 4$ & 64 & $14.08 \pm 2.67$ & $773.74 \pm 165.04$ & $10.50 \pm 1.62$ & -23.72 & 0.23 \\
\hline
\end{tabular}

ind. - individuals; DGL - diameter at ground level (above the root cone); SD - standard deviation; PC - principal component.

As expected, the fragment with most restrictive protection status and longer history of protection (F1) had densities similar to those of populations sampled in other long-protected areas in the Una region (Martini, unpublished data; Silva et al. 2009), in contrast with F2, F3, and F4, which had lower densities. The Una region is a mosaic of forest fragments and secondary effects of disturbance gradients have been observed within this landscape (Faria et al. 2009). During the process of forest fragmentation, many threats to the ecosystem are facilitated, including logging, game hunting, and extraction (Tabarelli et al. 2004). Although we attempted to avoid visibly harvested areas, we cannot exclude the possibility that palm hearts were exploited at any given site, especially because such activity has often been observed at Una (A.M.Z. Martini, personal communication). Albeit important, legal protection status alone cannot guarantee the survival and maintenance of palm populations across fragmented landscapes in the Atlantic Forest Biome (Portela et al. 2010a). Brazilian law allows the creation of conservation areas with different degrees of protection, from fully protected public sites to sustainably managed private areas (SNUC 2000). Therefore, the degree of protection status combined with the time since gaining that status apparently greatly influences plant demography in the Una region, given that higher densities were found for areas that have been more strictly protected for longer periods of time.

In the present study the proportion of Euterpe edulis seedlings ranged from ca. $0.5 \%$ to $11.8 \%$, well below the $73 \%$ reported by Reis et al. (2000). The formation of abundant seedling banks is a characteristic strategy of the species (Reis et al. 1996). Similar patterns of low E. edulis seedling bank densities have been observed in areas impacted by harvesting (Portela 2008) and intense seed predation (Fadini et al. 2009).

There are a number of factors that could explain the reduced Euterpe edulis seed production in the Una region. First, it is possible that reduced fertility (low seed output) is characteristic of the "Bahia" ecotype, which would decrease the probability of successful seed germination at favorable sites, as well as hindering recruitment, thereby limiting the size of the population (Horvitz \& Schemske 1995). Second, post-dispersal seed predation rates might regulate seed establishment (Fadini et al. 2009). Studies have revealed high rates of seed predation in E. edulis, ranging from $71 \%$ to $82 \%$ in the same forest fragments in the Una region (Melito 2011). Seed predation could lead to a seed-to-seedling bottleneck, given that low probabilities of seedling establishment were observed in the fragments examined (Melito 2011). Recruitment will be greatly affected by high rates of seed predation, as was observed by Fadini et al. (2009) in areas of Atlantic Forest on Anchieta Island (in the state of São Paulo). The seeds of E. edulis suffer predation by vertebrates such as small rodents (Vieira et al. 2003) and white-lipped peccaries (Keuroghlian \& Eaton 2008), as well as by specialist scolytid beetles (Allmen et al. 2004). These seed predator-plant interactions can vary by season (All- 
men et al. 2004), by microhabitat (Fleury \& Galetti 2004), or even by the level of defaunation (Galetti et al. 2006). The foraging behaviors of generalist rodents can respond to $E$. edulis abundance by preying on more seeds at lower (rather than higher) plant densities (Pizo \& Vieira 2004). Distinct seed predation patterns in the Una fragments (Melito 2011) could explain the variations seen in the seedling/adult ratio. Third, annual variations in seed production are common in E. edulis populations, because the numbers of adults and the numbers of inflorescences per plant both oscillate on a yearto-year basis (Fantini \& Guries 2007; Matos \& Watkinson 1998). A year of low seed production is usually followed by a reproduction peak, maintaining the influx of individuals into the regeneration bank (Fantini \& Guries 2007; Matos \& Watkinson 1998). Therefore, the greater density of E. edulis in the sapling stage observed for the Una populations in the present study indicate that new individuals were being recruited into the regeneration banks. It is of note that $E$. edulis shows synchronic reproductive phenology (Castro et al.2007). To avoid a potential temporal bias, we sampled all of the forest fragments at the end of the fructification period.

In Euterpe edulis, seedling density is usually related to the number of reproductive individuals (Marcos \& Matos 2003; Fantini \& Guries 2007). However, we did not observe that pattern at the Una sites studied here (except in F2). The survival of $E$. edulis seedlings is generally low and can fluctuate widely among years (Portela et al. 2010b). In the Una region, the high rates of seed predation and low rates of seedling recruitment (Melito 2011) are likely to have a negative affect on the seedling/adult ratio (but not the sapling/ adult ratio), because of the continuous influx of individuals into the regeneration banks.

The density of Euterpe edulis was lower in F2 than in the other Una fragments studied, although the proportional distribution of plants by developmental stage was similar among the fragments. In F2, the density of adults (30 individuals/ha) was lower than the threshold of 50-60 adults/ha considered necessary for the maintenance of natural stands (Freckleton et al. 2003). In addition, we found only one seedling in the F2 sample plots. That, combined with the low density of adult plants, resulted in the seedling/adult ratio being lowest for F2, which also had the lowest densities of saplings and juveniles. Although these patterns might have occurred because only a very low-density patch of this population was sampled, they could also indicate that something is limiting seedling establishment. Seedling establishment is affected indirectly by microhabitat heterogeneity and directly by the negative effects of human activities, such as movement through the area and logging (Portela \& Santos 2009). The seed limitation processes commonly seen in areas from which adult individuals have been removed or in which the soil has been disturbed lead to restricted seed recruitment (Clark et al. 2007). Although we did not observe any signs of palm heart harvesting at the sites evaluated in the present study, it is possible that it was practiced in the past and that this population is still recovering from the effects of those activities.

The lowest scores for the immature and adult stages were observed in the biplot for F3. Those scores were heavily influenced by the lower values for the plant size parameters, especially DGL and plant height. Sample plots in F3 also showed dissimilarities in the proportions of individuals, especially saplings. Although palm heart harvesting generally focuses on the largest plants (Matos \& Bovi 2002), immature individuals will also be taken if there are few reproductive individuals (Matos \& Bovi 2002). Reductions in the abundance of larger individuals of Euterpe edulis tend to favor the growth of younger individuals (Silva Matos et al. 1999; Fantini \& Guries 2007).

Certain situations that affect immature plants can be a serious concern, because this stage comprises the future reproductive individuals (Bruna et al. 2009). Models estimate more profound impacts on demographic structures when mortality (harvesting) is directed at immature rather than reproductive individuals of Euterpe edulis (Freckleton et al. 2003). To obtain accurate estimates of the regeneration potential of these populations, recruitment into the immature stage should be monitored, as should survival and growth.

The differences in Euterpe edulis plant sizes were generally more accentuated in the larger sizes classes, especially in terms of DGL and height. The number of leaves has been shown to vary less than do diameter and height in E. edulis (Reis 1995). The shape of E. edulis plants changes over the course of development, because stem diameter does not correlate directly with height (Alves et al. 2004). Plants up to $1.25 \mathrm{~m}$ in height will allocate resources to widen the stem base, establishing support for later height gains (Silva 1991; Alves et al. 2004). Silva et al. (2009) suggested that low soil fertility and a closed canopy environment caused by high plant density influences development in E. edulis in the Una region, resulting in individuals that are taller and thinner than are those in other populations. As previously noted, harvesting also influences plant size.

Plants in F1 were taller than were those in the other fragments probably because of the absence of harvesting there and higher solar radiation levels along the river bank (Silva 1991). Site quality will influence plant size, as will resource allocation for reproduction (Nathan \& Muller-Landau 2000). Fertility has been found to be related to greater access to sunlight (Silva 1991) but not to stem diameter (Matos \& Watkinson 1998), and it can positively influence population abundance. The high investment in radial growth seen at F2 might reflect a strategy for competing under the dense canopies observed in older forests or (most likely) might indicate a regenerating population that was affected by past harvesting.

Our results suggest that the Una populations studied, with the exception of the $\mathrm{F} 2$ population, exhibit the threshold level of adult densities, as estimated by Freckleton et al. (2003), required in order to ensure natural regeneration by the continuous input of seedlings into these populations. 
However, it is necessary to quantify the viability of these populations in order to guarantee their temporal persistence, especially because of the low densities observed for all developmental stages, as well as the lower seed production of the "Bahia" ecotype present in the Una region. This approach is especially necessary in the F2 population, which presented the lowest density, not only in the Una region but also in northeastern Brazil at large. The rates of seed predation and seedling establishment influence the demographic rates (e.g., mortality and survivorship) and must be evaluated in order to monitor the continuous recruitment of individuals into those populations. On the basis of this information, the conservation status of E. edulis in its northernmost range can be recognized and guidelines for sustainable management can be established. We also underscore the great variations among the forest fragments in the Una region, suggesting that the conservation of E. edulis in this landscape must be conducted on a regional scale.

\section{Acknowledgments}

We thank Rodrigo Fadini and Adriana M. Z. Martini, who made their data on Euterpe edulis density available; Carolina M. Pinheiro, Fred Hobus, Lukas H. Daneu, and Thiago R. F. Araújo, for their assistance during the fieldwork; and Yonaldo Guedes, for granting us permission to carry out our study on his property. Special thanks go to Bruno Machena, (ICMBio-REBIO Una- Instituto Chico Mendes de Conservação da Biodiversidade da Reserva Biológica de Una) and Tatiana Alves (ICMBio-RVS Una - Instituto Chico Mendes de Conservação da Biodiversidade do Refúgio de Vida Silvestre de Una) for all of their support in conducting this work. We are also grateful to the Universidade Estadual de Santa Cruz (UESC), the CEPEC Herbarium of the Centro de Pesquisas do Cacau (CEPLAC), and the ICMBio-REBIO Una, for the logistic support and infrastructure provided. This study received financial support from the Fundação de Amparo à Pesquisa do Estado da Bahia (FAPESB, grant no. BOL0524/2009), the UESC (Grant no. 00220.1100.773), the UESC Master's Program in Ecology and Conservation, and the Brazilian Conselho Nacional de Desenvolvimento Científico e Tecnológico (CNPq,; productivity grant no. DEB 306992/2012-4 to AMA).

\section{References}

Alger, K. \& Caldas, M. 1994. The declining cocoa economy and the Atlantic forest of Southern Bahia, Brazil: conservation attitudes of cocoa planters. Environmentalist 14(2): 107-119.

Allmen, C.V.; Morellato, L.P.C. \& Pizo, M. A. 2004. Seed predation under high seed density condition: the palm Euterpe edulis in the Brazilian Atlantic Forest. Journal of Tropical Ecology 20(4): 471-474.

Alves, L.F.; Martins, F.R. \& Santos, F.A.M. 2004. Allometry of a neotropical palm, Euterpe edulis Mart. Acta Botanica Brasilica 18(2): 369-374.

Amorim, A.M.; Thomas, W.; Carvalho, A.M.V. \& Jardim, J.G. 2008. Floristics of the Una Biological Reserve, Bahia, Brazil. Pp. 67-146. In: W.
Thomas (Ed.). The Atlantic Coastal Forest of Northeastern Brazil, The New York Botanical Garden Press, Bronx, New York.

Andreazzi, C.S.; Pires, A.S. \& Fernandez, F.A.S. 2009. Mamíferos e palmeiras neotropicais: interações em paisagens fragmentadas. Oecologia Brasiliensis 13(4): 554-574.

Bovi, M.L., Godoy Jr, G. \& Sáes, L.A. 1987. Pesquisas com o gênero Euterpe e Bactris no Instituto Agronômico de Campinas. $\mathbf{O}$ agronômico 39(2): 129-174.

Bruna, E.M. \& Kress, W.J. 2002. Habitat fragmentation and the demographic structure of an amazonian understory herb (Heliconia acuminata). Conservation Biology 16(5): 1256-1266.

Bruna, E.M.; Fiske, I.J. \& Trager, M.D. 2009. Habitat fragmentation and plant populations: is what we know demographically irrelevant? Journal of Vegetation Science 20(3): 569-576.

Carvalho Filho, R.; Melo, A.A.; Santana, S.O. \& Leão, A.C. 1987. Solos do município de Ilhéus. Comissão Executiva do Plano da Lavoura Cacaueira, Ilhéus, BA.

Castro, E.R.; Galetti, M. \& Morellato, PC. 2007. Reproductive phenology of Euterpe edulis (Arecaceae) along a gradient in the Atlantic rainforest of Brazil. Australian Journal of Botany 55(7):725-735.

Clark, C.J.; Poulsen, J.R.; Levey, D.J. \& Osenberg, C.W. 2007. Are plant populations seed limited? A critique and meta-analysis of seed addition experiments. The American Naturalist 170(1): 128-42.

Coelho, G. 2010. Estrutura genética populacional em morfotipos de Euterpe edulis. Master thesis, Ilheus, UESC.

Donoso, D.S., Grez, A.A. \& Simonetti, J.A. 2003. Effects of forest fragmentation on the granivory of differently sized seeds. Biological Conservation 115(1): 63-70.

Fadini, R.F.; Fleury, M.; Donatti, C.I. \& Galetti, M. 2009. Effects of frugivore impoverishment and seed predators on the recruitment of a keystone palm. Acta Oecologica 35(2): 188-196.

Fantini, A. \& Guries, R. 2007. Forest structure and productivity of palmiteiro (Euterpe edulis Martius) in the Brazilian Mata Atlântica. Forest Ecology and Management 242(2-3): 185-194.

Faria, D.; Mariano-Neto, E.; Martini, A.M.Z.; Ortiz, J.V.; Montingelli, R.; Rosso, S.; Paciencia, M.L.B. \& Baumgarten, J. 2009. Forest structure in a mosaic of rainforest sites: The effect of fragmentation and recovery after clear cut. Forest Ecology and Management 257(11): 2226-2234.

Fleury, M. \& Galetti, M. 2004. Effects of microhabitat on palm seed predation in two forest fragments in southeast Brazil. Acta Oecologica 26(3): 179-184.

Freckleton, R.P.; Matos, D.M.S.; Bovi, M.L. \& Watkinson, A.R. 2003. Predicting the impacts of harvesting using structured population models: the importance of density-dependence and timing of harvest for a tropical palm tree. Journal of Applied Ecology 40(5): 846-858.

Gabriel, K.R. 1971. The biplot graphic display of matrices with application to principal component analysis. Biometrika 58(3): 453-467.

Galetti, M. \& Aleixo, A. 1998. Effects of palm heart harvesting on avian frugivores in the Atlantic rain forest of Brazil. Journal of Applied Ecology 35(2): 286-293.

Galetti, M.; Donatti, C.I.; Pires, A.S.; Guimaraes, P.R. \& Jordano, P. 2006. Seed survival and dispersal of an endemic Atlantic forest palm: the combined effects of defaunation and forest fragmentation. Botanical Journal of the Linnean Society 151(1): 141-149.

Galetti, M. \& Fernandez, J.C. 1998. Palm heart harvesting in the Brazilian Atlantic forest: changes in industry structure and the illegal trade. Journal of Applied Ecology 35(2): 294-301.

Henderson, A.; Galeano, G. \& Bernal, R. 1995. Field guide to the palms of the Americas. New Jersey, Princeton University Press.

Horvitz, C.C. \& Schemske, D.W. 1995. Spatiotemporal variation in demographic transitions of a tropical understory herb: projection matrix analysis. Ecological Monographs 65(2): 155-192.

Hulme, P.E. 1998. Post-dispersal seed predation: consequences for plant demography and evolution. Perspectives in Plant Ecology, Evolution and Systematics 1(1): 32-46.

Keuroghlian, A. \& Eaton, D.P. 2008. Removal of palm fruits and ecosystem engineering in palm stands by white-lipped peccaries (Tayassu pecari) and other frugivores in an isolated Atlantic Forest fragment. Biodiversity and Conservation 18(7): 1733-1750. 
Marcos, C.S. \& Matos, D.M.S. 2003. Estrutura de populações de palmiteiro (Euterpe edulis Mart.) em áreas com diferentes graus de impactação na floresta da Tijuca, RJ. Floresta e Ambiente 10(1): 27-37.

Martini, A.M.Z.; Fiaschi, P.; Amorim, A. \& Paixão, J.L. 2007. A hot-point within a hot-spot: a high diversity site in Brazil's Atlantic Forest. Biodiversity and Conservation 16: 3111-3128.

Matos, D.M.S \& Bovi, M. 2002. Understanding the threats to biological diversity in southeastern Brazil. Biodiversity and Conservation 11(10): 1747-1758

Matos, D.M.S. \& Watkinson, A. R. 1998. The fecundity, seed, and seedling ecology of the edible palm Euterpe edulis in Southeastern Brazil. Biotropica 30(4): 595-603.

Melito, M.O. 2011. Efeito da fragmentação florestal na predação de sementes e estrutura populacional de Euterpe edulis (Mart.) no sul da Bahia. Master thesis, Ilheus, UESC.

Mesquita, A.C. 1996. A atividade madeireira na região cacaueira. In: Alternativas para o desenvolvimento e conservação da região de Una. Resumos de pesquisa. Instituto de Estudos Sócio Ambientais do Sul da Bahia, IESB. Ilhéus, Bahia.

Meyer, F.S. \& Dornelles, S.S. 2003. Demografia do palmiteiro Euterpe edulis (Arecaceae) na floresta ombrófila densa de terras baixas em regeneração, na região da Vila da Glória, São Francisco do Sul (SC). Revista Saúde e Ambiente 4(2): 7-13.

Mori, S.A.; Boom, B.B.; Carvalho, A.M. \& Santos, T.S. 1983. Southern Bahia moist forests. The Botanical Review 49(2):155-232.

Nathan, R. \& Muller-Landau, H. 2000. Spatial patterns of seed dispersal, their determinants and consequences for recruitment. Trends in Ecology \& Evolution 15(7): 278-285.

Pardini, R. 2001. Pequenos mamíferos e a fragmentação da Mata Atlântica de Una, Sul da Bahia - Processos e Conservação. Ph.D. thesis, São Paulo, USP.

Pardini, R. 2004. Effects of forest fragmentation on small mammals in an Atlantic forest landscape. Biodiversity and Conservation 13(13): 2567-2586.

Pizo, M. a \& Vieira, E.M. 2004. Palm harvesting affects seed predation of Euterpe edulis, a threatened palm of the Brazilian Atlantic Forest. Brazilian Journal of Biology 64(3b): 669-76

Portela, R.D.C. 2008. Ecologia populacional de três espécies de palmeiras em uma paisagem fragmentada no domínio da Mata Atlântica, RJ. Ph.D. thesis, Campinas, UNICAMP.

Portela, R.D.C.; Bruna, E.M. \& Santos, F.A.M. 2010a. Demography of palm species in Brazil's Atlantic forest: a comparison of harvested and unharvested species using matrix models. Biodiversity and Conservation 19(8): 2389-2403.

Portela, R.D.C.; Bruna, E.M. \& Santos, F.A.M. 2010b. Are protected areas really protecting populations? A test with with an Atlantic rain forest palm. Tropical Conservation Science 3(4): 361-372.

Portela, R.D.C. \& Santos, F.A.M. 2009. Mortality and mechanical damage of seedlings in different size fragments of the Brazilian Atlantic Forest. Tropical Ecology 50(2): 267-275.

R Development Core Team. 2009. A language and environment for statistical computing. Vienna, R Foundation for Statistical Computing.

Raupp, S.V., Brack, P. \& Carvalho Leite, S.L. 2009. Aspectos demográficos de palmiteiro (Euterpe edulis Mart.) em uma área da Floresta
Atlântica de Encosta em Maquiné, Rio Grande do Sul. IHERINGIA 64(1): 57-61.

Reis, A. 1995. Dispersão de sementes de Euterpe edulis Martius (Palmae) em uma Floresta Ombrófila Densa Montana da encosta atlântica em Blumenau, SC. Ph.D. thesis, Campinas, UNICAMP.

Reis, A.; Kageyama, P.Y.; Reis, M.S. \& Fantini, A. 1996. Demografia de Euterpe edulis Martius (Arecaceae) em uma Floresta Ombrófila Densa Montana, em Blumenau (SC). Sellowia 45-48: 13-45.

Reis, M.S.; Fantini, A.C.; Nodari, R.O.; Reis, A.; Guerra, M.P. \& Mantovani, A. 2000. Management and conservation of natural populations in Atlantic rain forest: the case study of palm heart (Euterpe edulis Martius). Biotropica 32(4b): 894-902.

Saatchi, S. Agosti, D., Alger, K., Delabie, J. \& Musinsky, J. 2001. Examining fragmentation and loss of primary forest in the southern Bahian Atlantic Forest of Brazil with radar imagery. Conservation Biology 15(4): 865-875.

Scariot, A. 1999. Forest fragmentation effects on palm diversity in central Amazonia. Journal of Ecology 87(1): 66-76.

Silva Matos, D.M. 2000. Herbivore and plant demography: a case study in a fragment of semi-deciduous forest in Brazil. Journal of Tropical Ecology 16(1): 159-165.

Silva Matos, D.M.; Freckleton, R.P. \& Watkinson, A.R. 1999. The role of density dependence in the population dynamics of a tropical palm. Ecology 80(8): 2635-2650.

Silva, D.M. 1991. Estrutura de tamanho e padrão espacial de uma população de Euterpe edulis Mart. (Arecaceae) em mata mesófila semidecídua no município de Campinas, SP. Master thesis, Campinas, UNICAMP.

Silva, M.D.G.C.P.C.; Martini, A.M.Z. \& Araújo, Q.R.D. 2009. Estrutura populacional de Euterpe edulis Mart. no Sul da Bahia, Brasil. Revista Brasileira de Botânica 32(2): 393-403.

SNUC. 2000. Sistema Nacional de Unidades de Conservação. Lei ${ }^{\circ}$ 9.985, de 18 de julho de 2000 .

Tabarelli, M.; Cardoso da Silva, J.M. \& Gascon, C. 2004. Forest fragmentation, synergisms and the impoverishment of neotropical forests. Biodiversity and Conservation 13(7): 1419-1425.

Thomas, W.W., Carvalho, A.M.V., Amorim, A.M., Hanks, J.G. \& Santos, T.S. 2008. Diversity of woody plants in the Atlantic forest of southern Bahia, Brazil. Pp. 21-66. In: W.W. Thomas (ed.). The Atlantic Coastal Forest of Northeastern Brazil. New York, The New York Botanical Garden Press.

Thomas, W.M.W.; Carvalho, A.M.V.D.E.; Amorim, A.M.A.; Garrison, J. \& Arbeláez, A.L. 1998. Plant endemism in two forests in southern Bahia, Brazil. Biodiversity and Conservation 7(3): 311-322.

Uhl, N.W. \& Dransfield, J. 1987. Genera Palmarum. A classification of palms based on the work of Harold E. Moore, Jr. Lawrence, Allen Press.

Vieira, E.; Pizo, M. \& Izar, P. 2003. Fruit and seed exploitation by small rodents of the Brazilian Atlantic forest. Mammalia 67(4): 533-540.

Virillo, C.B.; Martins, F.R.; Tamashiro, J.Y \& Santos, F.A.M. 2011. Is size structure a good measure of future trends of plant populations? An empirical approach using five woody species from the Cerrado (Brazilian savanna). Acta Botanica Brasilica 25(3): 593-600.

Zar, J. 2009. Biostatistical analysis. Eglewood Cliffs. Prentice-Hall. 